\title{
Effect of breastfeeding piperine on the learning of offspring mice: interaction with caffeine and diazepam
}

This article was published in the following Dove Press journal:

Journal of Experimental Pharmacology

23 July 2010

Number of times this article has been viewed

\author{
Ali Akbar Moghadamnia ${ }^{1,2}$ \\ Vahid Zangoori ${ }^{2}$ \\ Seyed Sadegh Zargar-Nattaj ${ }^{2}$ \\ Pooya Tayebi² \\ Yasaman Moghadamnia ${ }^{3}$ \\ Seyed Gholam Ali Jorsaraei ${ }^{4}$ \\ 'Cellular and Molecular Biology \\ Research Center, Department of \\ Pharmacology, ${ }^{2}$ Department of \\ Pharmacology, ${ }^{3}$ Department of \\ Physics, Alzzahra University, Babol \\ University of Medical Sciences, Tehran, \\ Iran; ${ }^{4}$ Department of Anatomical Iran; \\ Sciences and Embryology, Tehran, Iran
}

Correspondence: Ali Akbar Moghadamnia Cellular and Molecular Biology Research Center, Department of Pharmacology, Babol University of Medical Sciences, 47I764I367, Babol, Iran

$\mathrm{Tel}+989 \mid$ | 31|| 0490

Fax +98 II I $22947 / 8$

Emailmoghadamnia@yahoo.com
Abstract: Piperine, the main alkaloid of black pepper (Piper nigrum), has been suggested to display several pharmacological properties, including pain relief, anticonvulsant, antidepressantlike, antianxiety, sedative, and anti-inflammatory effects. This study was designed to investigate the effect of piperine on learning in mice and the interaction of the effect with caffeine and diazepam. Piperine (100 mg/kg intraperitoneally) was injected into the mouse mothers or nursing dams during breastfeeding for 25 days at five-day intervals. After feeding the newborn mice, their learning was evaluated using a step-through passive avoidance task. Mouse learning was assessed $1 \mathrm{hr}$ and $24 \mathrm{hr}$ and 1 week after a training session. Piperine increased learning in the first $(1 \mathrm{hr}$ : $243.33 \mathrm{~s}$ vs $55.17 \mathrm{~s}, P=0.002$ ) and third assessments ( 1 week: $226 \mathrm{~s}$ vs $97 \mathrm{~s}, P<0.05$ ) posttraining, but no significant change was seen at the second $(24 \mathrm{hr})$ assessment. Piperine improved the effect of a low dose of caffeine ( $25 \mathrm{mg} / \mathrm{kg}$ intraperitoneally after a shock of $2 \mathrm{~s}$ duration) in a first assessment ( $295.17 \mathrm{~s}$ vs $149.17 \mathrm{~s}, P=0.026$ ) compared to a higher dose of caffeine. Piperine reversed diazepam ( $1 \mathrm{mg} / \mathrm{kg}$ intraperitoneally) suppression of learning 24 hours after training by a 4 s shock ( $298 \mathrm{~s}$ vs $135.67 \mathrm{~s}, P=0.03$ ). According to the results, piperine alone significantly increased learning 1 hour and 1 week after training assessments, and learning can be improved in the short term when followed by piperine administration. It was also shown that piperine can potentiate the effect of a low dose of caffeine and can reverse the effect of diazepam.

Keywords: piperine, piper nigrum, caffeine, diazepam, learning, memory, breastfeeding, step-through passive avoidance task

\section{Introduction}

Despite the many studies conducted on learning and memory, the exact mechanisms of learning and memory remain unknown. It has been suggested that some neurotransmitters such as epinephrine, serotonin and dopamine play a role in memory. ${ }^{1}$ Within the last decade, many investigations have been focused on the effects of drugs, including herbal drugs, on the learning process. ${ }^{2}$ Piperine is a major alkaloid of black pepper (Piper nigrum), which is used as a pungent food additive, flavoring, and antiflatulent in Iranian folk medicine. Piper species have been used in folk medicine for the treatment of various diseases.

Pharmacological studies have shown that piperine reduces inflammation and pain, ${ }^{3}$ possesses anticonvulsant and antiulcer activity, ${ }^{4,5}$ protects the liver, ${ }^{6}$ has deleterious effects on testis function, ${ }^{7}$ and cytoprotective and antioxidant activity. ${ }^{8}$ Results from previous studies demonstrated that piperine showed anxiolytic and antidepressantlike activity. ${ }^{910}$ Piperine also inhibited monoamine oxidase (MAO) activity, ${ }^{9-11}$ and increased the levels of noradrenaline and serotonin in some regions of the mouse brain. ${ }^{10}$ 
However, there are no reliable data in the literature on the effect of piperine on learning among the second generation of mice that receive piperine during their infant life, or later during nursing. Since piperine can be secreted in the milk, ${ }^{12}$ and in order to explore the influences of piperine on learning, the present study was designed to examine the effect of piperine on learning among the second generation of mice that receive piperine during their infant life via breastfeeding.

\section{Materials and methods}

This animal study was approved by the Research Ethics Committee at Babol University of Medical Sciences, and was performed based on accepted guidelines.

\section{Animals}

Albino mice weighing 20-30 g were purchased from the Pasteur Institute in Tehran, Iran. Mating pairs were housed in separate cages for breeding at a room temperature of $22 \pm 1^{\circ} \mathrm{C}$ with a 12-hour light/dark cycle. The pregnant mice were then randomly divided into two groups, case and control, and were kept in separate cages until delivery. The mother and the newborn mice were kept together in the cage until the infant mice weighed up to 20-30 g. Treatment commenced on the first day after delivery, and all injections were performed on the mothers. Case mothers were given piperine $(100 \mathrm{mg} / \mathrm{kg}$ intraperitoneally), the main alkaloid of black pepper, from the first day to the twenty-fifth day (at five-day intervals) after delivery. The controls were given saline as placebo. In the next phase of the experiment, caffeine and diazepam were immediately given to the second generation mice after a training session. All passive avoidance performance experiments were done on the second generation mice in a quiet room in the morning to minimize levels of noise and stress that could disturb the learning process.

\section{Drugs}

Piperine (Merck, Darmstadt, Germany), diazepam hydrochloride (1 and $5 \mathrm{mg} / \mathrm{kg}$ intraperitoneally; Daru Pakhsh, Tehran, Iran) and caffeine (25 and $50 \mathrm{mg} / \mathrm{kg}$ intraperitoneally; Sigma Chemical, St Louis, MO, USA.) were administered as previously described.

\section{Step-through passive avoidance task}

The apparatus used for the assessment of memory in mice was designed based on Muromachi Kikai's study ${ }^{13}$ with a few modifications. It had two chambers, including bright $(10 \times 12 \times 15 \mathrm{~cm})$ and dark $(14 \times 18 \times 15 \mathrm{~cm})$ compartments. A narrow wooden wall with a guillotine door separated the chambers. The bright chamber was colored white. The test was carried out in 3 days. On the first day, or training session, mice were individually placed in the bright compartment and were allowed to have free movement for $30 \mathrm{~s}$. Afterwards, the guillotine door was raised to allow them to enter the dark compartment. The floor of the chamber was equipped with a network of wires to supply an electrical shock $(0.01 \mathrm{~mA}$, $60 \mathrm{~V})$ to the mice entering the dark chamber. The electrical shock was delivered for 2 or $4 \mathrm{~s}$, after which the mice were removed from the cages. In the test sessions, learning was assessed at $1 \mathrm{hr}, 24 \mathrm{hr}$, and 1 week after the training session using the step-through passive avoidance task without shock. For this test, mice were placed in the bright compartment and allowed to explore for $30 \mathrm{~s}$. The door was then raised and the latency time it took for them to enter the dark compartment was recorded up to $300 \mathrm{~s}$. This period of time was considered a measurement of the level of learning.

\section{Pain threshold}

The reaction of mice to electrical shock in the dark chamber of the passive avoidance device was evaluated as pain threshold. Mice were allowed 10 minutes to familiarize to the surroundings of the device before they received six different intensities of electrical shock $(0.1,0.2,0.3,0.4,0.5$, and $0.6 \mathrm{~mA}$ ). Shock duration was $2 \mathrm{~s}$, given at $20 \mathrm{~s}$ intervals. Jumping and flinching (forepaws off the grid floor) were considered as indicating the threshold of pain sensation. ${ }^{13}$

\section{Statistical analysis}

The data are presented as the mean \pm standard deviation (SD). The Mann-Whitney U test was applied for comparing the medians of two different groups for each session. The KruskalWallis $\mathrm{H}$ test and the Friedman test were used when comparing more than two different groups and for comparing the data of the three sessions of training assessment between or within each test group. The surveillance of the main event (avoidance of entering the dark chamber after training) was analyzed using the Kaplan-Meier test. Differences between groups were considered statistically significant at $P$ values less than 0.05 .

\section{Results}

\section{Comparison of passive avoidance performance between mice receiving saline and piperine pretreatment after saline (placebo) injection}

The mean latency time to enter the dark compartment in the piperine pretreatment group was increased at $1 \mathrm{hr}$ and 
1 week after the training session when compared to the saline pretreatment group (55.17 s vs $243.33 \mathrm{~s}, P=0.002$; and 97 s vs 226 s, $P<0.05$, Figure 1, Table 1). Surveillance analysis showed a significant difference between the two groups at $1 \mathrm{hr}(P=0.011$, Figure 2$)$. The placebo groups entered the shock room faster than the piperine groups at $1 \mathrm{hr}$ (149.83 s vs $219.8 \mathrm{~s}), 24 \mathrm{hr}$ (116.50 s vs $240.6 \mathrm{~s})$ and 1 week (131.83 s vs $143.8 \mathrm{~s})$ after piperine administration (Table 2).

\section{Comparison of passive avoidance performance between mice receiving caffeine or placebo in saline pretreated mice}

The mean latency times at $1 \mathrm{hr}, 24 \mathrm{hr}$, and 1 week, after $2 \mathrm{~s}$ shock duration, were $55.17 \mathrm{~s}$ vs $149.17 \mathrm{~s}, 142 \mathrm{~s}$ vs $228.5 \mathrm{~s}$, and $97 \mathrm{~s}$ vs $201.50 \mathrm{~s}$ respectively $(P>0.05$, Table 1$)$. The mean latency time increased among the caffeine $(50 \mathrm{mg} / \mathrm{kg})$ group that had been pretreated with saline compared to the saline group with similar pretreatment $(55.17 \mathrm{~s}$ vs $300 \mathrm{~s}$ at $2 \mathrm{~s}$ shock duration, and $149.81 \mathrm{~s}$ vs $257.83 \mathrm{~s}$ at 4 s shock duration). This latency time was greater among the higher dose than the low-dose caffeine groups $(257.83 \mathrm{~s}$ vs $131.80 \mathrm{~s}$ at 4 s shock duration, Tables 1, 2). Kaplan-Meier surveillance analysis showed a significant difference between the caffeine $(25 \mathrm{mg} / \mathrm{kg}$ ) group pretreated by saline and exposed to shock $(2 \mathrm{~s})$ and the caffeine $(25 \mathrm{mg} / \mathrm{kg})$ group pretreated by saline and shock (4 s) when the latency time was measured at $24 \mathrm{hr}$ after the shock $(P=0.035$, Figure 3$)$.

\section{Comparison of passive avoidance performance between mice receiving caffeine after saline or piperine pretreatment}

A significant difference between mean latency times was recorded $1 \mathrm{hr}$ after the shock (2 s) training session in the group pretreated with piperine before caffeine administration, compared to those receiving saline as a pretreatment (149.17 s vs $295.17 \mathrm{~s}, P=0.026$, Figure 4 ). Also, the difference between the group receiving caffeine $(50 \mathrm{mg} / \mathrm{kg})$ pretreated with piperine and the group receiving saline with the same pretreatment was considerable (300 s vs $205.50 \mathrm{~s}$ ), but changes were statistically significant only at $1 \mathrm{hr}$ after the shock (4 s) training session $(257.8 \mathrm{~s}$ vs $182.84 \mathrm{~s}, P=0.046)$. On the other hand, the trend of these changes at a dose $50 \mathrm{mg} / \mathrm{kg}$ of caffeine is opposite to that seen at a low dose of caffeine. Surveillance analysis showed the same results as those shown between the caffeine $(25 \mathrm{mg} / \mathrm{kg})$ group pretreated with saline and piperine $(P=0.041$, Figure 5).

The Kruskal-Wallis H test confirmed a significant difference between data of the 25 and $50 \mathrm{mg} / \mathrm{kg}$ caffeine groups pretreated with saline and piperine only at the test session that occurred $1 \mathrm{hr}$ after training $(P<0.05)$. This finding was also

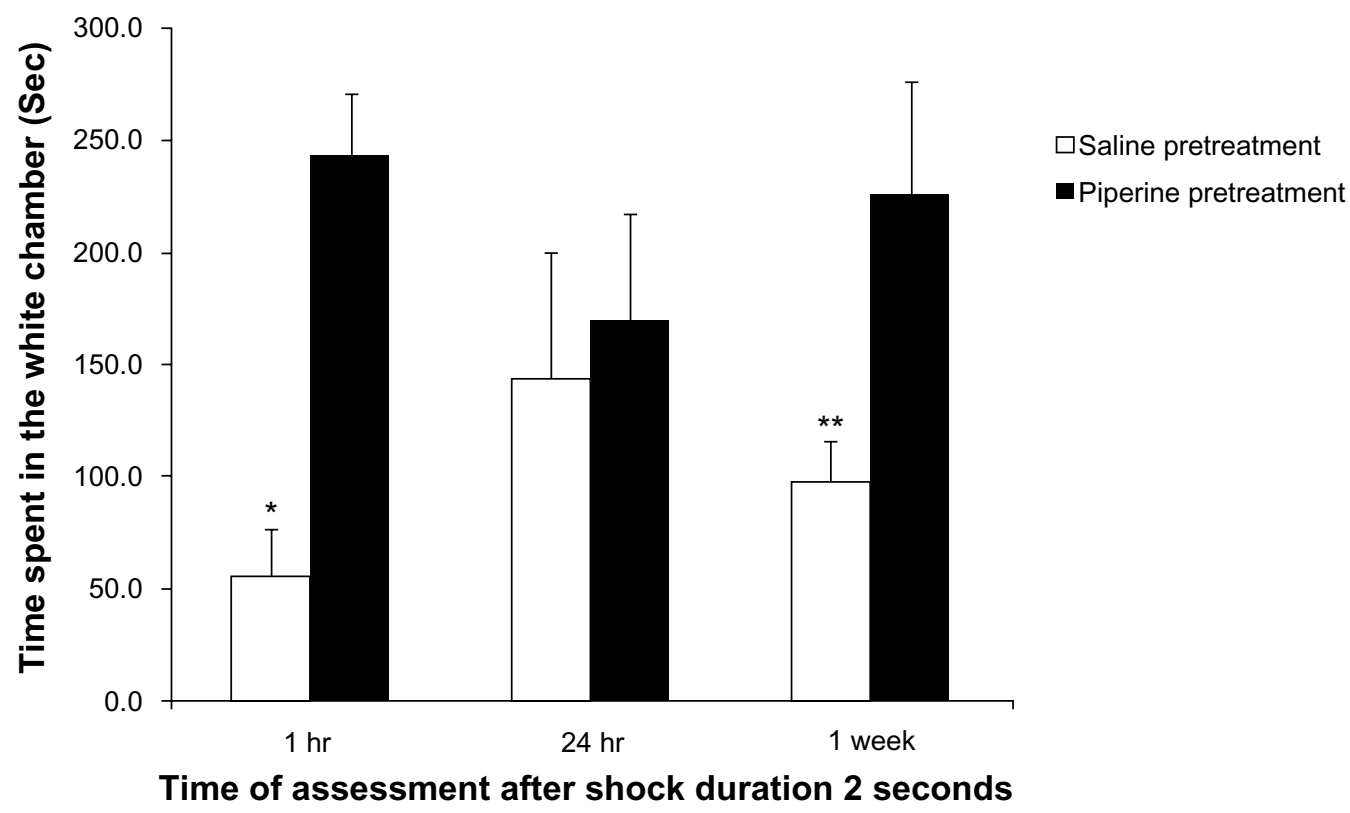

Figure I Mean time (seconds \pm SEM) spent in the white chamber (avoidance behavior after $2 \mathrm{~s}$ shock) by mice $(\mathrm{n}=12)$ receiving saline pretreatment or piperine $(100 \mathrm{mg} / \mathrm{kg}$ ) pretreatment at different times after training.

Abbreviations: SEM, standard error of the mean; $\mathrm{mg} / \mathrm{kg}$, milligrams per kilogram; hr, hour; s, second. Notes: ${ }^{*} P=0.002$. ${ }^{* *} P<0.05$. 
Table I Mean time (seconds \pm SEM) spent in the white chamber by mice that were given a shock of $2 \mathrm{~s}$ duration $(\mathrm{n}=\mathrm{I} 2)$

\begin{tabular}{|c|c|c|c|c|}
\hline Group & I hr & $24 \mathrm{hr}$ & I week & $P$ value ${ }^{* * *}$ \\
\hline Saline pretreatment + saline & $55.17 \pm 14.66$ & $142 \pm 39.78$ & $97 \pm 13.19$ & NS \\
\hline Piperine $(100 \mathrm{mg} / \mathrm{kg})$ pretreatment + saline & $243.33 \pm 19.16$ & $169.33 \pm 33.36$ & $226 \pm 35.11$ & NS \\
\hline$P$ value ${ }^{*}$ & 0.002 & NS & 0.05 & - \\
\hline Saline pretreatment + caffeine $25 \mathrm{mg} / \mathrm{kg}$ & $149.17 \pm 29.93$ & $228.50 \pm 24.41$ & $201.50 \pm 29.15$ & NS \\
\hline Piperine pretreatment + caffeine $25 \mathrm{mg} / \mathrm{kg}$ & $295.17 \pm 2.74$ & $235 \pm 16.54$ & $258.33 \pm 18.44$ & \\
\hline$P$ value & 0.026 & NS & NS & - \\
\hline Saline pretreatment + caffeine $50 \mathrm{mg} / \mathrm{kg}$ & $300 \pm 0$ & $262 \pm 26.59$ & $178.33 \pm 30.90$ & 0.023 \\
\hline Piperine pretreatment + caffeine $50 \mathrm{mg} / \mathrm{kg}$ & $205.50 \pm 31.18$ & $197.83 \pm 32.21$ & $119.33 \pm 32.21$ & NS \\
\hline$P$ value & NS & NS & NS & - \\
\hline
\end{tabular}

Abbreviations: SEM, standard error of the mean; hr, hour; NS, not significant; s, second.

Notes: "Mann-Whitney $U$ test was used for comparison between two groups. ${ }^{* *}$ Compared by Friedman test.

confirmed by Kaplan-Meier surveillance analysis $(P<0.05$, Figure 6). The Friedman test showed a significant difference within the group of caffeine $(50 \mathrm{mg} / \mathrm{kg})$ mice pretreated with saline at the two different shock levels (for $2 \mathrm{~s}$ and $4 \mathrm{~s}$, $P=0.023$ and $P<0.05$ respectively, Tables 1,2$)$. There was a significant discrepancy between mice treated with $25 \mathrm{mg} / \mathrm{kg}$ caffeine ( $1 \mathrm{hr}$ after $4 \mathrm{~s}$ shock) and $50 \mathrm{mg} / \mathrm{kg}(1 \mathrm{hr}$ after $2 \mathrm{~s}$ shock $)$ in groups pretreated with saline $(P=0.043$, Tables 1, 2, Figure 7).

\section{Comparison of the effect of diazepam on passive} avoidance performance between mice pretreated with saline and piperine

The results obtained for the group receiving a dose of diazepam $(1 \mathrm{mg} / \mathrm{kg})$ did not show significant differences after $4 \mathrm{~s}$ shock training compared to those receiving a higher dose $(5 \mathrm{mg} / \mathrm{kg})$ of diazepam $(296.67 \mathrm{~s}$ vs $251.2 \mathrm{~s}$ at $1 \mathrm{hr}$ after $4 \mathrm{~s}$ duration shock, Table 3, Figure 8). On the other hand, mice that received $1 \mathrm{mg} / \mathrm{kg}$ diazepam after pretreatment with

\section{Survival functions}

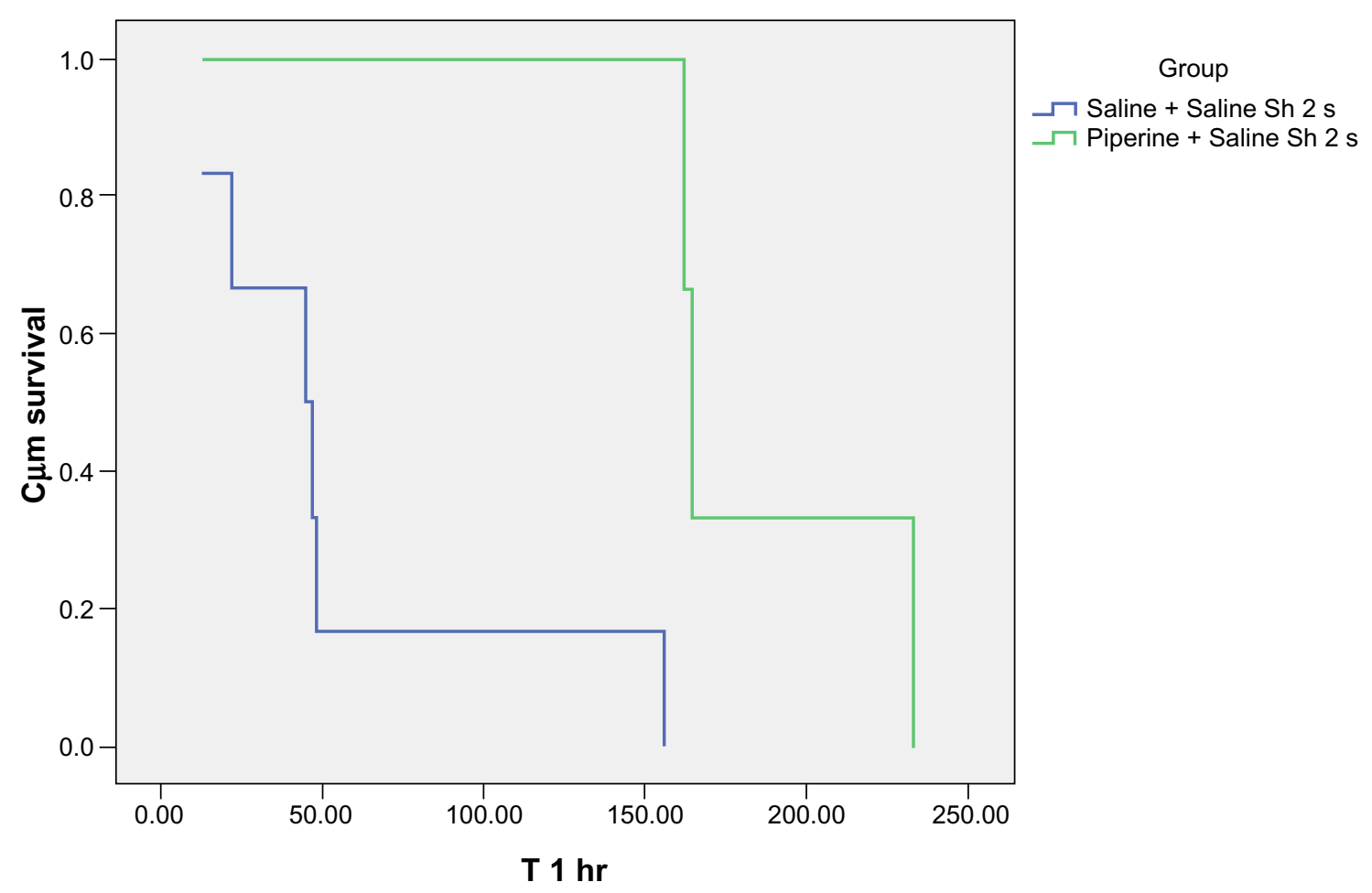

Figure 2 Kaplan-Meier surveillance curve comparing the trend of events (entering or not entering the dark chamber) by mice in each group ( $\mathrm{n}=\mathrm{I} 2$ ) at $\mathrm{I}$ hr after training by $2 \mathrm{~s}$ shock. Comparison of mice that received saline but different pretreatments: saline or piperine $(\mathrm{I} 00 \mathrm{mg} / \mathrm{kg})$. Significant differences were seen between groups $(P=0.0 \mathrm{I} \mathrm{I})$. Abbreviations: hr, hour; s, second; mg/kg, milligrams per kilogram. 
Table 2 Mean time (seconds \pm SEM) spent in the white chamber by mice that were given a shock of $4 \mathrm{~s}$ duration $(n=12)$

\begin{tabular}{|c|c|c|c|c|}
\hline Group & I hr & $24 \mathrm{hr}$ & I week & $P$ value ${ }^{* *}$ \\
\hline Saline pretreatment + saline & $|49.8| \pm 40.04$ & $\mathrm{I} \mid 6.50 \pm 40.70$ & $131.83 \pm 39.40$ & NS \\
\hline Piperine $(100 \mathrm{mg} / \mathrm{kg})$ pretreatment + saline & $219.8 \pm 24.96$ & $240.6 \pm 17.14$ & $143.8 \pm 40.85$ & NS \\
\hline$P$ value ${ }^{*}$ & NS & NS & NS & - \\
\hline Saline pretreatment + caffeine $25 \mathrm{mg} / \mathrm{kg}$ & $131.80 \pm 33.12$ & $\mid 12.79 \pm 27.31$ & $163.50 \pm 37.40$ & NS \\
\hline Piperine pretreatment + caffeine $25 \mathrm{mg} / \mathrm{kg}$ & $285 \pm 36.74$ & $300 \pm 0$ & $215.5 \pm 116.91$ & \\
\hline$P$ value & 0.026 & 0.002 & NS & - \\
\hline Saline pretreatment + caffeine $50 \mathrm{mg} / \mathrm{kg}$ & $257.80 \pm 29.51$ & $221.33 \pm 34.65$ & $183.60 \pm 40.92$ & 0.05 \\
\hline Piperine pretreatment + caffeine $50 \mathrm{mg} / \mathrm{kg}$ & $182.84 \pm 27.87$ & $210.78 \pm 30.84$ & $168 \pm 34.19$ & NS \\
\hline$P$ value & 0.046 & NS & NS & - \\
\hline
\end{tabular}

Abbreviations: SEM, standard error of the mean; hr, hour; NS, not significant; s second.

Notes: "Mann-Whitney $U$ test was used for comparison between two groups. " Compared by Friedman test.

piperine spent a longer amount of time in the white chamber compared to those that received the same dose of diazepam but were pretreated with saline $(298 \mathrm{~s}$ vs $135.67 \mathrm{~s}$ at $24 \mathrm{hr}$ after shock, $P=0.03$ ). Within-group analysis by the Friedman test showed statistically significant intra-group variations in mice receiving $1 \mathrm{mg} / \mathrm{kg}$ diazepam with saline pretreatment $(P=0.021)$ but not piperine pretreatment $(P=0.83$, Table 3).

\section{Discussion}

The aim of this study was to understand the effect of piperine on learning and memory in the offspring of mice that received piperine during breastfeeding. Based on the present study, it can be suggested that piperine can potentiate short- and long-term learning after training. This enhancement may be due to the metabolic role of piperine in the central nervous system.

\section{Survival functions}

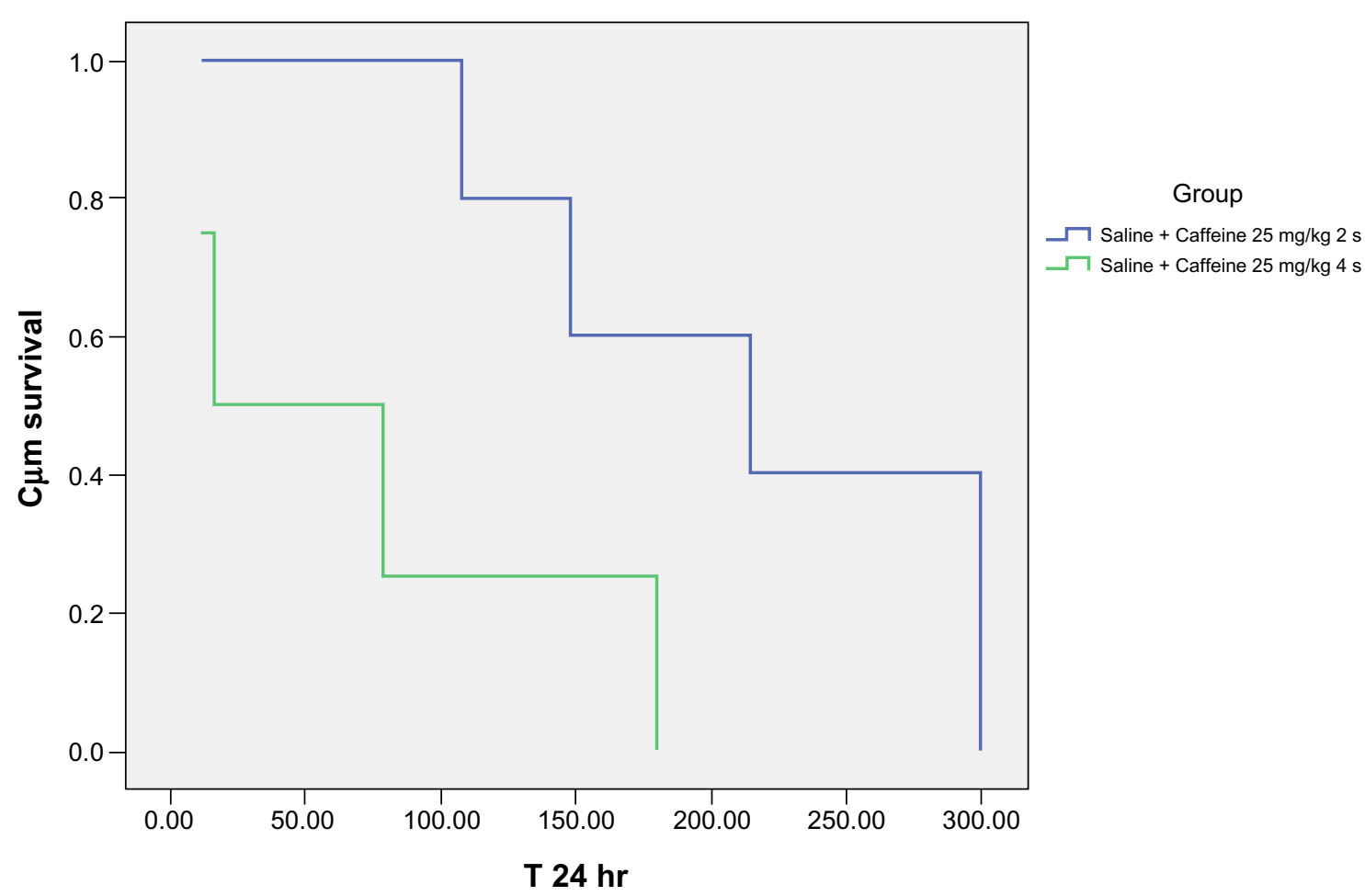

Figure 3 Kaplan-Meier surveillance curve comparing the trend of events (entering or not entering the dark chamber) by mice ( $\mathrm{n}=12$ ) at 24 hr after training by $2 \mathrm{~s}$ and $4 \mathrm{~s}$ shock. Comparison between mice that received $25 \mathrm{mg} / \mathrm{kg}$ caffeine pretreated with saline, and $2 \mathrm{~s}$ shock, and the same treatment with $4 \mathrm{~s}$ shock). Significant differences were seen between groups $(P=0.035)$.

Abbreviations: hr, hour; s, second; mg/kg, milligrams per kilogram. 


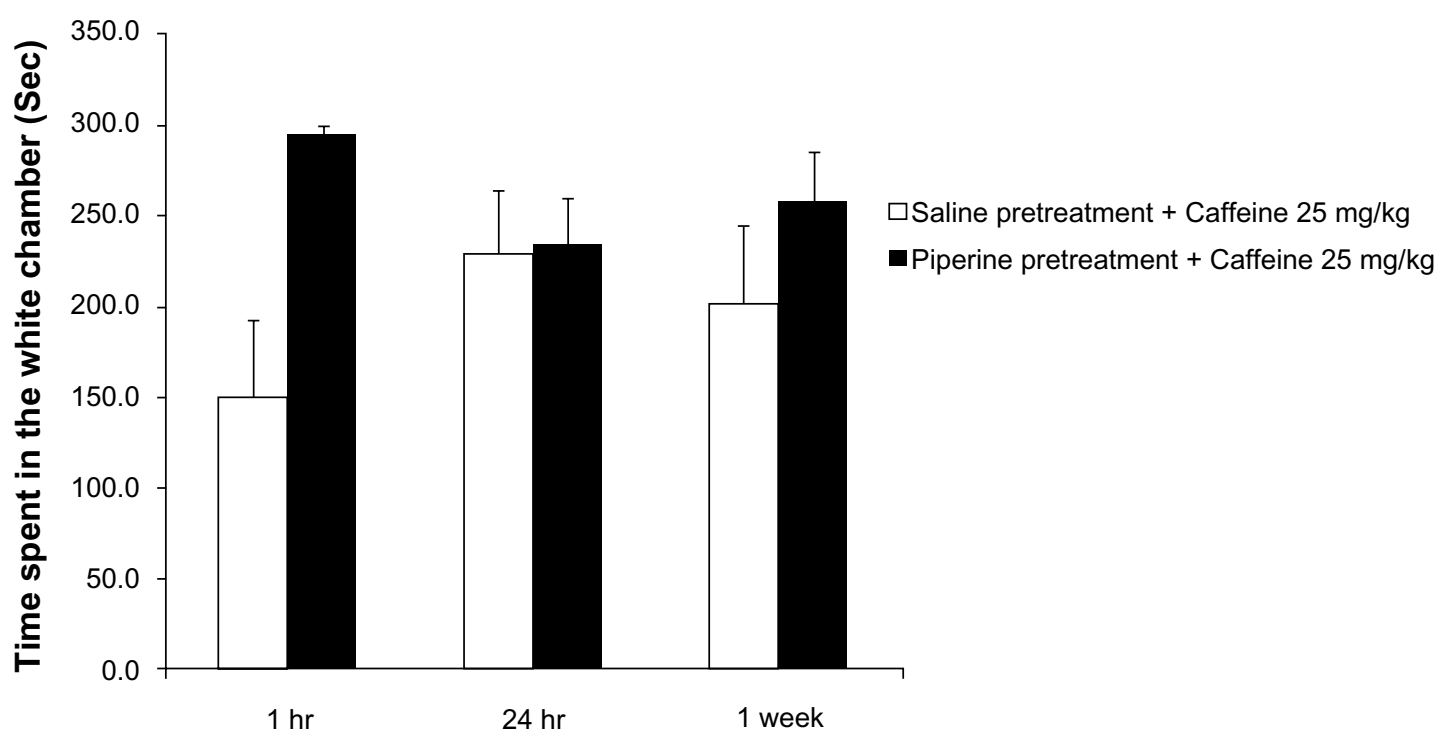

Time of assessment after shock duration 2 seconds

Figure 4 Mean time (seconds \pm SEM) spent in the white chamber (avoidance behavior after $2 \mathrm{~s}$ shock) of mice $(\mathrm{n}=12)$ receiving caffeine $(25 \mathrm{mg} / \mathrm{kg})$ pretreated with saline or piperine $(100 \mathrm{mg} / \mathrm{kg})$ at different times after training.

Abbreviations: SEM, Standard error of the mean; hr, hour; s, second; $\mathrm{mg} / \mathrm{kg}$, milligrams per kilogram.

Note: ${ }^{*} P=0.026$.

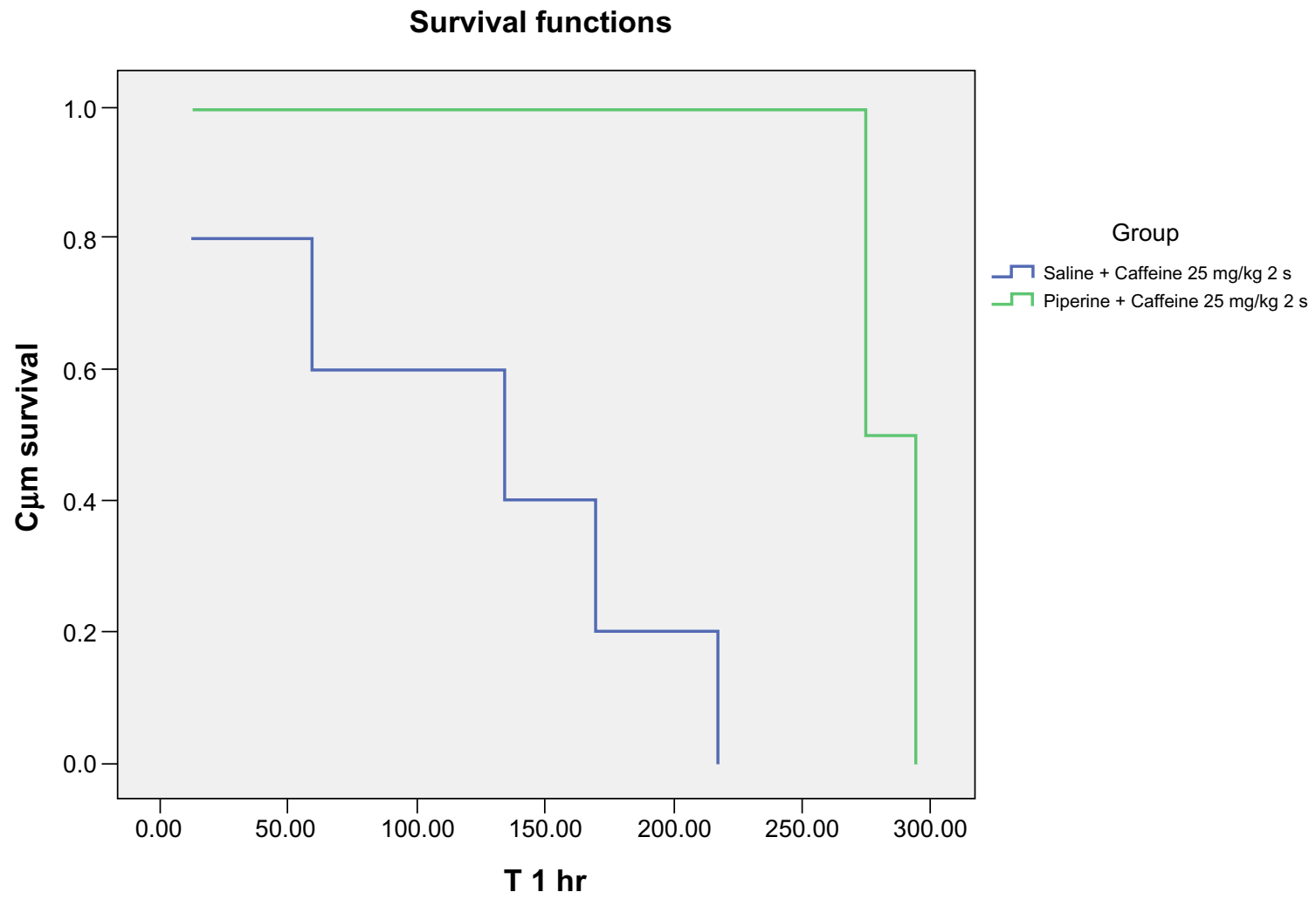

Figure 5 Kaplan-Meier surveillance curve comparing the trend of events (entering or not entering the dark chamber) by mice in each group ( $\mathrm{n}=\mathrm{I2}$ ) at I hr after training by $2 \mathrm{~s}$ shock. Comparison between mice that received $25 \mathrm{mg} / \mathrm{kg}$ caffeine and were pretreated with saline, and those that received $25 \mathrm{mg} / \mathrm{kg}$ caffeine and were pretreated with piperine ( $100 \mathrm{mg} / \mathrm{kg})$. Significant differences were seen between groups $(P=0.04 \mathrm{I})$.

Abbreviations: hr, hour; s, second; $\mathrm{mg} / \mathrm{kg}$, milligrams per kilogram. 


\section{Survival functions}

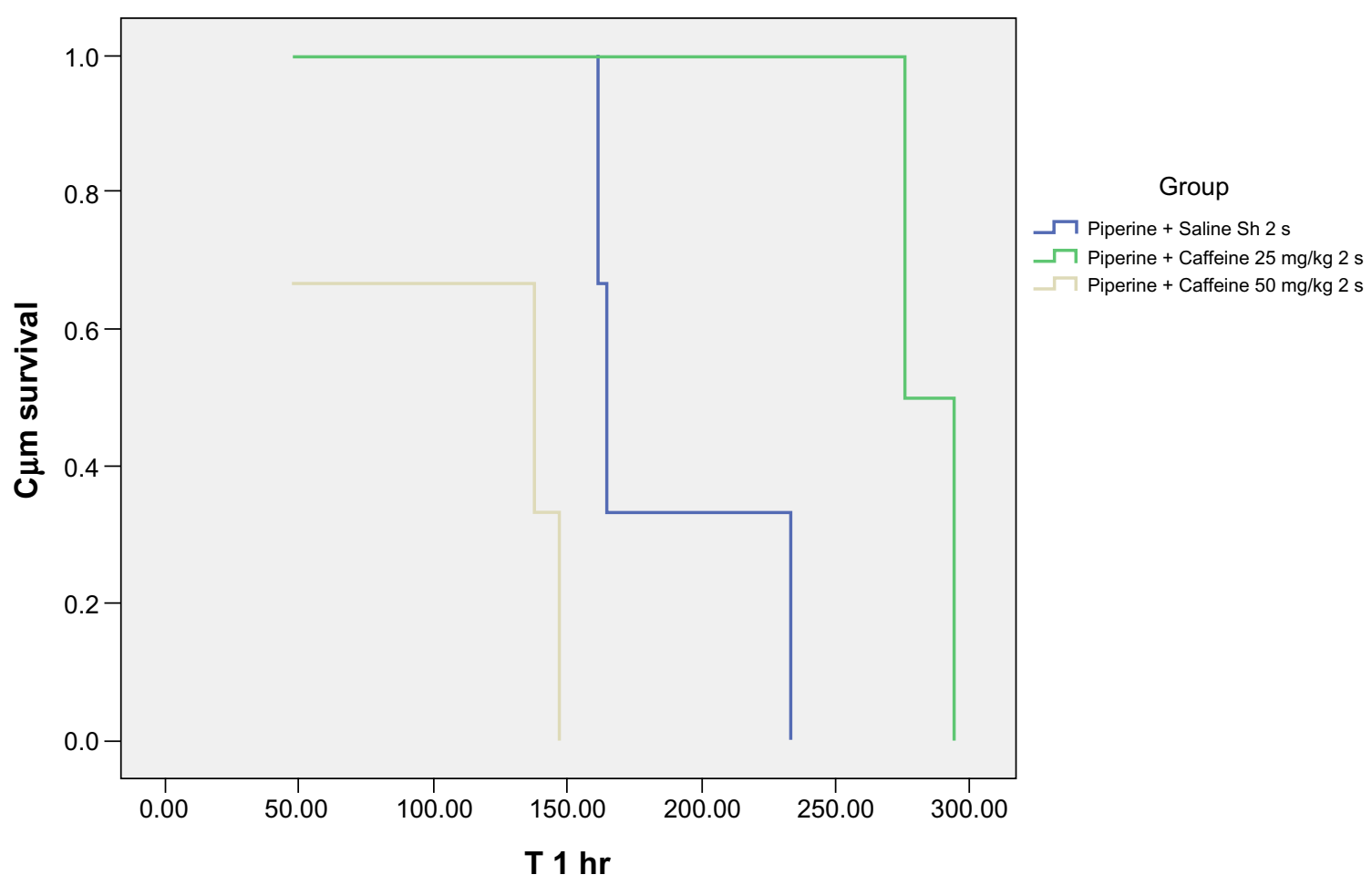

Figure 6 Kaplan-Meier surveillance curve comparing the trend of events (entering or not entering the dark chamber) by mice in each group $(\mathrm{n}=\mathrm{I} 2)$ at I hr after training by $2 \mathrm{~s}$ shock. Comparison between mice that received saline, caffeine $(25 \mathrm{mg} / \mathrm{kg})$ and caffeine $(50 \mathrm{mg} / \mathrm{kg})$ in the same piperine $(100 \mathrm{mg} / \mathrm{kg})$ pretreated groups. Significant differences were seen between groups at $P<0.005$.

Abbreviations: hr, hour; s, second; $\mathrm{mg} / \mathrm{kg}$, milligrams per kilogram.

None of the drugs at equal doses have shown significant effects on the nociception threshold for flinching and jumping. It is concluded that the effects of piperine, caffeine, and diazepam are due to modulating the learning process, not to changes in the nociception threshold.

Results from previous studies demonstrated that piperine inhibits MAO activity. ${ }^{9-11}$ Piperine, especially at low dose, is a potential alternative agent that may be used to improve brain function and enhance cognition. ${ }^{14}$ It has also been shown to increase the level of noradrenaline and serotonin in some regions of the mouse brain, ${ }^{10}$ and can modify noradrenalineand serotonin-mediated behavior. Hence, piperine may be a potential nootropic agent. ${ }^{15}$

Numerous transmitters have been reported to play roles in spatial memory, including glutamate, acetylcholine and serotonin. ${ }^{1}$ Several lines of evidence have suggested that there is a functional interaction between the cholinergic and serotonergic systems in the mediation of cognitive behavior. ${ }^{16-18}$ The serotonergic projection from the dorsal raphe nucleus to the hippocampus had also been demonstrated..$^{19}$ In recent years, serotonin has been reported to play a crucial role in acquisition and consolidation processes. ${ }^{20}$ Based on the role of serotonin on spatial memory and the effect of piperine on serotonin previously mentioned, we suggest that the cognitively enhancing effect of piperine may occur partly via the facilitation of acquisition and consolidation processes induced by the alteration in serotonin levels.

On the other hand, caffeine treatment increased the levels of brain 5-hydroxytryptophan (5-HT) and noradrenaline in mice. ${ }^{21}$

Caffeine activates noradrenergic and local dopaminergic neurons. Many of the alerting effects of caffeine may be related to the action of the methylxanthine on serotonin neurons. ${ }^{22}$ These findings could support a mechanism of positive interaction between caffeine and piperine in the passive avoidance learning of the present study. On the other hand, it has been reported that administration of diazepam can regionally decrease the level of 5-HT in the hippocampus. ${ }^{23}$ We showed that piperine can reverse the negative effect of diazepam on learning. It may be due to the positive effect exerted by piperine through increasing the levels of 5-HT in those regions. 


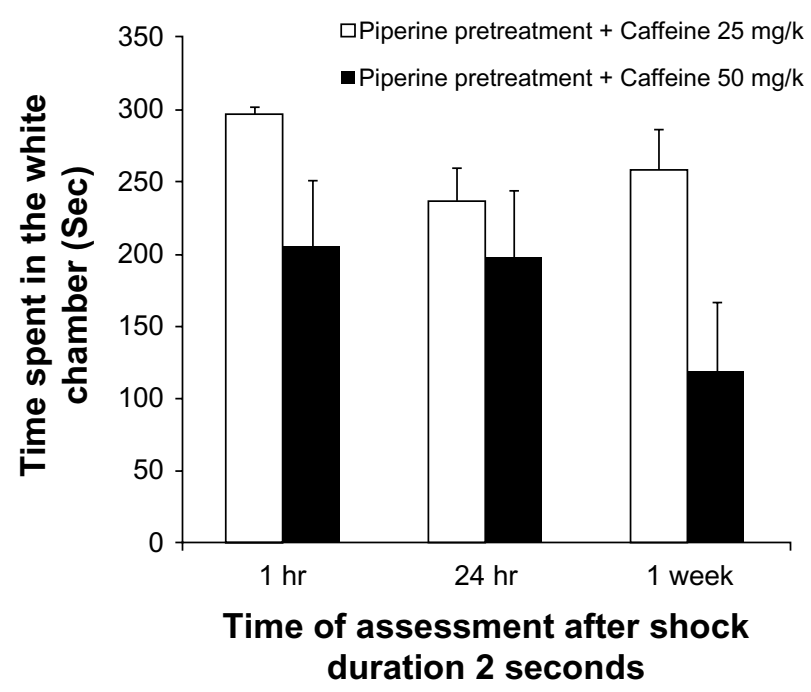

Figure 7 Mean time (seconds \pm SEM) spent in the white chamber (avoidance behavior after $4 \mathrm{~s}$ shock) by mice $(n=12)$ pretreated with piperine $(100 \mathrm{mg} / \mathrm{kg})$ receiving $25 \mathrm{mg} / \mathrm{kg}$ caffeine or $50 \mathrm{mg} / \mathrm{kg}$ caffeine at different times after training. No significant differences were seen between groups.

Abbreviations: SEM, Standard error of the mean; hr, hour; s, second; $\mathrm{mg} / \mathrm{kg}$, milligrams per kilogram.

However, the real mechanisms for piperine's effect on memory are still unknown. Many studies have suggested that caffeine has a dual effect: ie, that low-dose caffeine $(25 \mathrm{mg} / \mathrm{kg}$ ) improves memory quality, but a high dose (greater than $50 \mathrm{mg} / \mathrm{kg}$ ) does not. ${ }^{24}$ On the other hand, the effect could be dose-dependent. Caffeine is a nonselective competitive $\mathrm{A} 1$ and $\mathrm{A} 2{ }_{\mathrm{A}}$ receptor antagonist, and both receptors have similar affinities for caffeine. ${ }^{25}$ All four subtypes of adenosine receptors $\left(\mathrm{A} 1, \mathrm{~A} 2_{\mathrm{A}}, \mathrm{A} 2_{\mathrm{B}}\right.$, and $\mathrm{A} 3$ ) are heterogeneously distributed through the brain tissue, especially in the cortex and hippocampus. ${ }^{26}$ Activation of these receptors directly or indirectly decreases the release of acetylcholine from hippocampal neurons. ${ }^{27}$ Acetylcholine is a neurotransmitter that affects the process of memory and learning. ${ }^{28}$ Caffeine in lower doses $(25 \mathrm{mg} / \mathrm{kg})$ antagonizes A1 receptors and increases the release of acetylcholine, which improves memory. Some studies suggest that the effect of caffeine on learning is not dose-dependent: increased doses of caffeine increase the locomotor activity of mice, and thus, mice entered the dark compartment chaotically in the passive avoidance model; this result was not related to the suppressing effect of high-dose caffeine. ${ }^{29}$ This effect is thought to be related to the action of caffeine on $\mathrm{A} 2{ }_{\mathrm{A}}$ receptors. Activation of the $\mathrm{A} 2 \mathrm{~A}_{\mathrm{A}}$ receptor by caffeine likely influences dopaminergic neurotransmission. ${ }^{30}$

Piperine (20 mg daily for 7 days) can demonstrate an earlier $\mathrm{T}_{\text {max }}$ (time after drug administration when maximum plasma concentration is reached) and a higher $\mathrm{C}_{\max }$ (maximum plasma concentration) and AUC (area under the concentration curve) in the subjects who received drugs such as theophylline and propranolol. This could be exploited to achieve better therapeutic control and improved patient compliance. ${ }^{31}$ These drugs can be metabolized by a microsomal enzyme system such as cytochrome P450 1A2 (CYP1A2). ${ }^{32}$ Caffeine is a selective substrate for CYP1A2. ${ }^{33}$ It is suggested that piperine is more active against cytochrome P450 3A4 (CYP3A4) but has less effect on other CYP enzymes. ${ }^{34}$ Based on the different effects of caffeine in the present study, it seems that when piperine is pretreated in mice, caffeine concentration could likely be increased, and the different effect of caffeine in high dose will appear. This is in agreement with results previously reported. ${ }^{35}$ On the other hand, some researchers recently reported that caffeine can antagonize receptors for benzodiazepine in the brain. ${ }^{36}$

Benzodiazepines were first used by anesthesiologists in 1964, and it is well known that benzodiazepines have a negative effect on memory. ${ }^{37}$ This effect, especially in the encoding stage, has been previously confirmed. ${ }^{38}$ In our study, mice pretreated with piperine that were given diazepam had the longest average latency time compared to the saline group. This observation clearly showed that diazepam has a negative effect on memory. However, piperine can reverse its negative behavior over time.

Table 3 Mean time (seconds \pm SEM) spent in the white chamber by mice receiving diazepam that were given a shock of $4 \mathrm{~s}$ duration $(\mathrm{n}=12)$

\begin{tabular}{|c|c|c|c|c|}
\hline Group & I hr & $24 \mathrm{hr}$ & I week & $P$ value ${ }^{* *}$ \\
\hline Saline pretreatment + diazepam $(\mathrm{I} \mathrm{mg} / \mathrm{kg})$ & $296.67 \pm 2.1$ & $135.67 \pm 37.3$ & $211.5 \pm 44.5$ & 0.021 \\
\hline Piperine $(100 \mathrm{mg} / \mathrm{kg})$ pretreatment + diazepam $(\mathrm{I} \mathrm{mg/kg})$ & $295.6 \pm 4.4$ & $298 \pm 2$ & $295.4 \pm 4.6$ & NS \\
\hline$P$ value* $^{*}$ & NS & 0.03 & NS & - \\
\hline Saline pretreatment + diazepam $(5 \mathrm{mg} / \mathrm{kg})$ & $251.2 \pm 43.1$ & $187.3 \pm 53.9$ & $236.7 \pm 44.7$ & NS \\
\hline Piperine pretreatment + diazepam (5 mg/kg) & $296 \pm 2.5$ & $274.8 \pm 2.3$ & $246.6 \pm 53.5$ & NS \\
\hline$P$ value & NS & NS & NS & - \\
\hline
\end{tabular}

Abbreviations: SEM, standard error of the mean; hr, hour; NS, not significant; s, second.

Notes: "Mann-Whitney $U$ test was used for comparison between two groups. ${ }^{* *}$ Compared by Friedman test. 


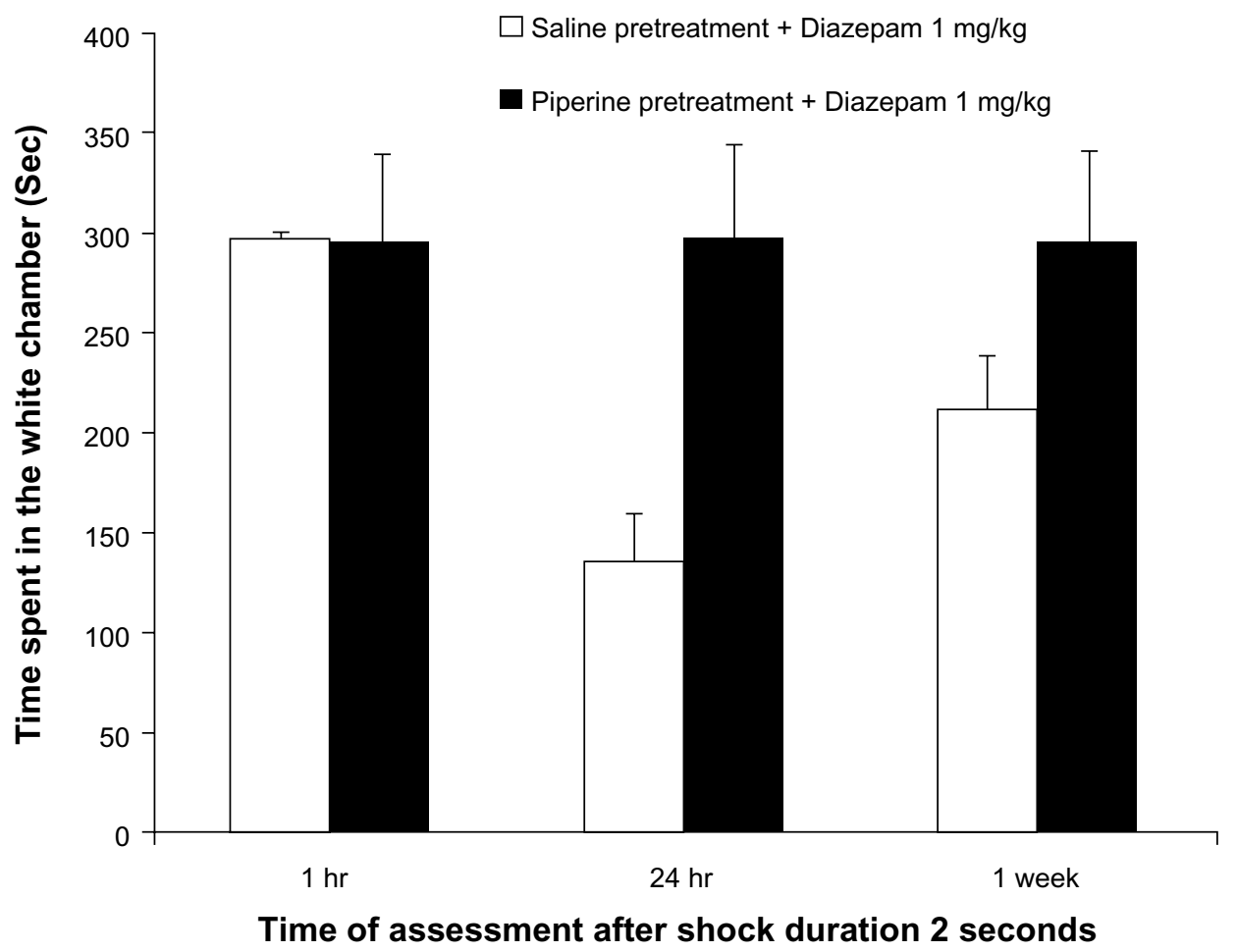

Figure 8 Mean time (seconds \pm SEM) spent in the white chamber (avoidance behavior after $4 \mathrm{~s}$ shock) by mice $(\mathrm{n}=\mathrm{I}$ ) pretreated with saline and receiving diazepam I mg/kg and those treated with piperine $(100 \mathrm{mg} / \mathrm{kg})$ and receiving diazepam I mg/kg at different times after training. Significant differences were seen between groups at $24 \mathrm{hr}$. Abbreviations: SEM, Standard error of the mean; hr, hour; s, second; $\mathrm{mg} / \mathrm{kg}$, milligrams per kilogram.

Note: ${ }^{*} P=0.03$

Based on our findings, we conclude that piperine has a positive effect on memory and learning. However, further investigations about the precise underlying mechanism and the development of basic molecular models to increase specificity of the target are still necessary.

\section{Acknowledgments}

The authors wish to thank Ms Zaker Abbasi, Mrs Hashemi, and Mr. Alijani for their laboratory and technical support.

\section{Disclosure}

The authors report no conflicts of interest in this work

\section{References}

1. Myhrer T. Neurotransmitter systems involved in learning and memory in the rat: a meta-analysis based on studies of four behavioral tasks. Brain Res Brain Res Rev. 2003;41(2-3):268-287.

2. Jin UH, Kim JH, Chang GT, Kim JK, Chung KH, Kim CH. Enhancement of learning and memory by a medicinal formulation, Saenhyetang, in mice. J Ethnopharmacol. 2007;109(2):271-280.

3. Gupta SK, Bansal P, Bhardwaj RK, Velpandian T. Comparative anti-nociceptive, anti-inflammatory and toxicity profile of nimesulide vs nimesulide and piperine combination. Pharmacol Res. 2000;41(6):657-662.

4. Bai YF, Xu H. Protective action of piperine against experimental gastric ulcer. Acta Pharmacol Sin. 2000;21(4):357-359.
5. D’Hooge R, Pei YQ, Raes A, Lebrun P, van Bogaert PP, de Deyn PP Anticonvulsant activity of piperine on seizures induced by excitatory amino acid receptor agonists. Arzneimittelforschung. 1996; 46(6):557-560.

6. Koul IB, Kapil A. Evaluation of the liver protective potential of piperine, an active principle of black and long peppers. Planta Med. 1993;59(5):413-417.

7. Malini T, Manimaran RR, Arunakaran J, Aruldhas MM, Govindarajulu P. Effects of piperine on testis of albino rats. J Ethnopharmacol. 1999; 64(3):219-225.

8. Selvendiran K, Singh JP, Krishnan KB, Sakthisekaran D. Cytoprotective effect of piperine against benzo[a]pyrene induced lung cancer with reference to lipid peroxidation and antioxidant system in Swiss albino mice. Fitoterapia. 2003;74(1-2):109-115.

9. Lee SA, Hong SS, Han XH, et al. Piperine from the fruits of Piper longum with inhibitory effect on monoamine oxidase and antidepressant-like activity. Chem Pharm Bull (Tokyo). 2005;53(7):832-835.

10. Li S, Wang C, Li W, Koike K, Nikaido T, Wang MW. Antidepressant-like effects of piperine and its derivative, antiepilepsirine. J Asian Nat Prod Res. 2007;9(3-5):421-430.

11. Kong LD, Cheng CH, Tan RX. Inhibition of MAO A and B by some plant-derived alkaloids, phenols and anthraquinones. J Ethnopharmacol. 2004;91(2-3):351-355.

12. Khachik F, Spangler CJ, Smith JC Jr, Canfield LM, Steck A, Pfander H. Identification, quantification, and relative concentrations of carotenoids and their metabolites in human milk and serum. Anal Chem. 1997;69(10):1873-1881

13. Tsuji M, Takeda H, Matsumiya T. Modulation of passive avoidance in mice by the 5-HT1A receptor agonist flesinoxan: comparison with the benzodiazepine receptor agonist diazepam. Neuropsychopharmacology. 2003;28:664-674. 
14. Wattanathorn J, Chonpathompikunlert P, Muchimapura S, Priprem A, Tankamnerdthai O. Piperine, the potential functional food for mood and cognitive disorders. Food Chem Toxicol. 2008;46(9): 3106-3110.

15. Hanumanthachar J, Milind P. Piperine on memory and behavior mediated via monoamine neurotransmitters. J Tradit Med. 2005;22(2):39-43.

16. Cassel JC, Jeltsch H. Serotonergic modulation of cholinergic function in the central nervous system: cognitive implications. Neuroscience. 1995;69(1):1-41.

17. Sirvio J, Riekkinen P Jr, Jakala P, Riekkinen PJ. Experimental studies on the role of serotonin in cognition. Prog Neurobiol. 1994;43(4-5): 363-379.

18. Steckler T, Sahgal A. The role of serotonergic-cholinergic interactions in the mediation of cognitive behaviour. Behav Brain Res. 1995; 67(2):165-199.

19. Kohler C, Chan-Palay V, Steinbusch H. The distribution and origin of serotonin-containing fibers in the septal area: a combined immunohistochemical and fluorescent retrograde tracing study in the rat. J Comp Neurol. 1982;209(1):91-111.

20. Orsetti M, Dellarole A, Ferri S, Ghi P. Acquisition, retention, and recall of memory after injection of RS67333, a 5-HT(4) receptor agonist, into the nucleus basalis magnocellularis of the rat. Learn Mem. 2003;10(5):420-426.

21. Chen MD, Lin WH, Song YM, Lin PY, Ho LT. Effect of caffeine on the levels of brain serotonin and catecholamine in the genetically obese mice. Zhonghua Yi Xue Za Zhi (Taipei). 1994;53(5):257-261.

22. Nehlig A, Daval JL, Debry G. Caffeine and the central nervous system: mechanisms of action, biochemical, metabolic and psychostimulant effects. Brain Res Brain Res Rev. 1992;17(2):139-170.

23. Haleem DJ, Batool F. Regionally specific effects of diazepam on brain serotonin metabolism in rats: sustained effects following repeated administration. Life Sci. 1996;59(15):PL239-PL246.

24. Angelucci ME, Cesario C, Hiroi RH, Rosalen PL, Da Cunha C. Effects of caffeine on learning and memory in rats tested in the Morris water maze. Braz J Med Biol Res. 2002;35(10):1201-1208.

25. Karcz-Kubicha M, Antoniou K, Terasmaa A, et al. Involvement of adenosine $\mathrm{A} 1$ and $\mathrm{A} 2 \mathrm{~A}$ receptors in the motor effects of caffeine after its acute and chronic administration. Neuropsychopharmacology. 2003;28(7):1281-1291.
26. Van Dort CJ, Baghdoyan HA, Lydic R. Adenosine A(1) and A(2A) receptors in mouse prefrontal cortex modulate acetylcholine release and behavioral arousal. J Neurosci. 2009;29(3):871-881.

27. Jin S, Johansson B, Fredholm BB. Effects of adenosine A1 and A 2 receptor activation on electrically evoked dopamine and acetylcholine release from rat striatal slices. J Pharmacol Exp Ther. 1993;267(2):801-808.

28. Gold PE. Acetylcholine modulation of neural systems involved in learning and memory. Neurobiol Learn Mem. 2003;80(3):194-210.

29. Angelucci MEM, Vital MABF, Cesário C, Zadusky CR, Rosalen PL, Cunha CD. The effect of caffine in animal model of learning and memory. Eur J Pharmacol. 1999;373(2-3):135-140.

30. Fredholm BB. Adenosine actions and adenosine receptors after 1 week treatment with caffeine. Acta Physiol Scand. 1982;115(2):283-286.

31. Bano G, Raina RK, Zutshi U, Bedi KL, Johri RK, Sharma SC. Effect of piperine on bioavailability and pharmacokinetics of propranolol and theophylline in healthy volunteers. Eur J Clin Pharmacol. 1991;41(6):615-617.

32. Xia CH, Sun JG, Wang GJ, et al. Herb-drug interactions: in vivo and in vitro effect of Shenmai injection, a herbal preparation, on the metabolic activities of hepatic cytochrome P450 3A1/2, 2C6, 1A2, and 2E1 in rats. Planta Med. 2010;76(3):245-250.

33. Turpault S, Brian W, Van Horn R, et al. Pharmacokinetic assessment of a five-probe cocktail for CYPs 1A2, 2C9, 2C19, 2D6 and 3A. BrJ Clin Pharmacol. 2009; 68(6):928-935.

34. Volak LP, Ghirmai S, Cashman JR, Court MH. Curcuminoids inhibit multiple human cytochromes P450, UDP-glucuronosyltransferase, and sulfotransferase enzymes, whereas piperine is a relatively selective CYP3A4 inhibitor. Drug Metab Dispos. 2008;36(8):1594-1605.

35. Zarrindast MR, Moghadamnia AA. Adenosine receptor agents and conditioned place preference. Gen Pharmacol. 1997;29(2):285-289.

36. Kaplan GB, Greenblatt DJ, Leduc BW, Thompson ML, Shader RI. Relationship of plasma and brain concentrations of caffeine and metabolites to benzodiazepine receptor binding and locomotor activity. J Pharmacol Exp Ther. 1989;248(3):1078-1083.

37. Brandt AL, Oakes FD: Preanesthesia Medication. Double-blind study of a new drug, diazepam. Anesth Analg. 1965;44:125-129.

38. Buffett-Jerrott SE, Stewart SH. Cognitive and sedative effects of benzodiazepine use. Curr Pharm Des. 2002;8(1):45-58.
Journal of Experimental Pharmacology

\section{Publish your work in this journal}

The Journal of Experimental Pharmacology is an international, peerreviewed, open access journal publishing original research, reports, reviews and commentaries on all areas of laboratory and experimental pharmacology. The manuscript management system is completely online and includes a very quick and fair peer-review system.

\section{Dovepress}

Visit http://www.dovepress.com/testimonials.php to read real quotes from published authors. 